\title{
Whistleblowing Intention and Organizational Commitment
}

\author{
Aruoren, Emmanuel Ejiroghene PhD. \\ Oboreh, Justina PhD. \\ Department of Business Administration \\ Delta State University, Abraka
}

\begin{abstract}
:
This study examined the relationship between whistleblowing intention and organizational commitment of commercial bank workers in Benin City, Edo State, Nigeria. A survey research design was adopted and a purposive sample of two hundred respondents was given copies of the questionnaire, out of which one hundred and ninety-one useful ones were retrieved. STATA statistical software package was used for the data analysis. The descriptive data analysis was carried out using mean and standard deviation, while reliability was tested using cronbach alpha coefficient. Furthermore, correlation and variance inflation factor (VIF) was used to test for multicollinearity among the independent variables. The research hypotheses were tested using multiple regression analysis. The study found a non-significant positive relationship between internal whistleblowing intention and organizational commitment. In addition, a significant positive relationship was found between external whistleblowing intention and organizational commitment. Based on this, the study recommended that commercial bank workers should be encouraged to develop organizational commitment as this would motivate them to blow the whistle when they discover wrongdoing or unethical behavior in their place of work. Future researchers should include other antecedents of whistleblowing as additional explanatory variables.
\end{abstract}

Keywords: Whistleblowing, Organizational commitment, Affective commitment, Continuance commitment, Normative commitment.

\section{Introduction:}

The pervasiveness of corruption in Nigerian public and private organizations over the last decade is alarming. Daily Trust (2019) reported the recent global anti-corruption watchdog, Transparency International (TI) ranking of Nigeria in the $148^{\text {th }}$ position out of 180 in its corruption perception index (CPI). Whistleblowing mechanism has been shown to be an effective tool in the fight against corruption (Onuora\&Uzoka, 2018). However, the decision to blow the whistle by individuals is a complex one and the whistleblowing policy in Nigeria is still at its infancy stage and so is research attention. Among the antecedents of whistleblowing is organizational commitment. Research has shown that employees with high level of organizational commitment are more likely to show pro-social behavior of whistleblowing than those with low levels of organizational commitment (Ahmad, George, \&Zubaidah, 2012).Although this is established in the literature, the relationship between the individual dimensions of organizational commitment and whistleblowing intentions is lacking. The purpose of this paper was therefore to examine the relationship between whistleblowing intentions and the three dimensional model of organizational commitment (affective, continuance and normative) (Allen \& Meyer, 1996).

\section{Literature Review}

\section{Whistleblowing:}

There are several definitions of whistleblowing, and most scholars describe it as pro-social, off-character, and organizational citizenship behavior. Chen (2019) describes whistleblowing behavior in the organization as an employee's whistleblowing on the illegal, destructive rules and unethical behaviors in the workplace, and is an effective mechanism to timely correction of non-ethical behavior in the organization. According to Jubb (1999), it is a deliberate non-obligatory act of disclosure, which gets onto public record and is made by a person who has or had privileged access to data or information of an organization, about non-trivial illegality or other wrongdoing whether actual, suspected or anticipated which implicates and is under the control of that organization, to an external entity having potential to rectify the wrongdoing. One of the most widely adopted definitions originates from Miceli, Dreyfus, \& Near (2014) who describe whistleblowing as the disclosure by members of organizations (former or current) of illegal, immoral or illegitimate practices under the control of their employers, to persons or organizations that may be able to effect action. 
These researchers therefore describe whistleblowing as a four step process: (1) A triggering event occurs, involving questionable, unethical, or illegal activities and this leads an employee to consider blowing the whistle; (2) The employee engages in decision making, assessing the activity and whether it involves wrongdoing, gathering additional information, and discussing the situation with others; (3) The employee exercises their voice by blowing the whistle; alternatively the employee could exit the organization, or remain silent out of loyalty or neglect; and (4) Organization members react to, and possibly retaliate against the whistleblower (Miceli, Dreyfus, \& Near, 2014).

Trevino \& Weaver (2001) refer to whistleblowing as a form of organizational citizenship behavior, which is a subset of pro-social behaviors in organizations. Thus, whistleblowing as one of the pro-social behaviors, is an act done by organizational members to convey direction, procedure, or policy that they find as unethical, illegal, or possibly causing disaster to the long-term organizational goals to certain individuals or others who can make corrections against it. Organizational citizenship behavior (OCB) has been described as an individual behavior that is discretionary, beyond one's duties and employees having the extra role behavior may increase the organizational effectiveness and productivity (Nikolett\&Nawangsari, 2019).

The whistleblower has been described as "an actor who brings each fraud to light" (Dyck, Morse, \&Zingalas, 2010, p. 2216) or as an "insider who seek to rectify perceived organizational wrongdoing" (Jubb, 1999, p.79). According to Culiberg\&Mihelic (2017) if the whistleblower directs his or her revelations to persons within the organization such as top management, the audit committee, or direct supervisors, the complainantis called internal whistleblower. On the other hand, if the whistleblower turns to an external body such as the media, the government, or any law enforcement agency, the complainant is considered an external whistleblower. Thus, whistleblowing in organization is usually either internal or external.

There are two types of methods that most existing studies adopt in measuring whistleblowing behavior. First, the actual whistleblowing behavior is measured. The respondents select the dichotomous variable according to the recall, such as "Is it reported to the internal supervisors after the discovery of the unethical behavior?". The second is to solve the difficulty of measuring the actual whistleblowing behavior by measuring the intention to whistleblowing. Questions such as "If I find misconduct in the workplace, I will whistle blow this to my supervisor" (Park, Rehg, \& Lee, 2005).

\section{Organizational commitment:}

The relationship between employees and their employing organizations has attracted a lot of attention over the last decade (Stinglhamber,Marique, Caesens, Desmette, Hansez, Hanin,\& Bertrand, 2015), hence the concept of organizational commitment has generated great attention (Albdour\&Altarawneh, 2014). Researches on organizational commitment (OC) have indicated that $\mathrm{OC}$ is a spontaneous, organic process that develops through the association of an individual to the organization (Al-Jabari., \&Ghazzawi (2019).Organizational commitment (OC)refers to the bond that exists between the employee and the organization (Klein, Molloy \& Cooper, 2009). OC has also been described as the relative strength of an individual's identification with and involvement in a particular organization (Wang, Indridason, \& Saunders, 2010). Thus, it is characterized by: “(1) a strong belief in and acceptance of the organization's goals and values; (2) a willingness to exert considerable effort on behalf of the organization; and (3) a strong desire to maintain membership in the organization"(Mowday, Steers, \& Porter (1979, p. 226). According to Allen\& Meyer (1996), OC can be conceptualized as a psychological state that describes an employee's relationship with their organization and a propensity to continue the relationship with the organization. These researchers therefore proposed a three-component model of organizational commitment: (1) Affective commitment; (2) Continuance commitment; and (3) Normative commitment. An employee could feel any combination of these three dimensions of organizational commitment.

Affective commitment (AC) refers to an employee's emotional attachment to, identification with, and involvement in an organization (Allen\& Meyer, 1996). According to Singh \& Gupta (2015), the AC an employee has to the organization is determined by the choice to remain committed to the organization due to some emotional identification. Employees who possess a strong level of affective commitment continue to stay at an organization because they want to. They feel emotionally attached to an organization because it is a good fit for their personality and values, or because they feel competent in their work role. Determinants of affective commitment include organizational factors (decentralization and organizational justice perception) and individual factors (age, gender, marital status, educational level and organizational tenure).

Allen\& Meyer (1996) define continuance commitment (CC) as "awareness of the costs associated with leaving the organization" (p.11). It is calculative in nature because of the individual's insight or weighing of the costs and risks related to exiting the organization (Nishanthi\&Kailasapathy, 2018). Wang et al., (2010) describes CC as an individual's need to remain with the organization resulting from his/her recognition of the costs (tenure, pay, benefits, pensions and family commitment among others) associated with leaving the organization. 
The perception that there is an investment (time, money, effort, retirement funds, and friendships) that would be lost if an individual left the organization leads to the development of CC. Furthermore,, an evaluation of work opportunities can also lead to the development of CC. This perception of alternatives is based on job market conditions, the economy, perceived ability to get another job and perceived competence in the field.

Normative commitment (NC) refers to the mind-set of an obligation by employees to remain in their organization (Mercurio, 2015).It describes employees who stay in an organization because it is the right and moral thing to do. The reasons employees may feel this way are widely varied, but may include being socialized within the organization or having received advanced rewards such as tuition payments. The development of NC evolves from pressure individuals receive from their interactions within an organization and their internalization of those feelings. The internalization can be based on a belief about the appropriate level of loyalty that is supported by the organizational culture. It can also be based on perceived psychological contract which are those subjective beliefs about the obligations between the individual and the organization.

\section{The link between Whistleblowing intention and Organizational commitment:}

There are few studies that have examined the relationship between whistleblowing and organizational commitment and most of these studies did not consider the multi-dimensional nature of organizational commitment. O'Reilly \& Chatman (1986) found evidence for the existence of three types of psychological components in organizational commitment: compliance, identification, and internalization. They also found support for the proposition that organizational commitment based on identification and internalization is related to pro-social behaviours whereas commitment based on compliance is not. This finding is consistent with Becker \& Billings' (1993) empirical study that found support for the existence of organizational commitment profiles, one of which exhibited pro-social behavior more than the others.

Sims \& Keenan (1998) and Mesmer-Magnus \&Viswesvaran (2005) indicate that there was no relationship between whistleblowing tendency and organizational commitment. Hayati\&Wulanditya (2018) found that organizational commitment has a positive effect on the intention to conduct whistleblowing. Thus, the higher the level of organizational commitment owned by the employees, the higher the intention to do whistleblowing. Saygan (2011) contended that because of the repercussion to whistleblowing, employees may choose to be silent. Thus, proposing a negative relationship between whistleblowing and affective commitment and a positive relationship between continuance and normative commitment. Miceli, Near, \&Schwenk, (1991) and Manjughi\&Fasihizadeh (2012) found a positive significant relationship between organizational commitment and whistleblowing tendency.

\section{Research Hypotheses:}

Based on the above discussions, the researcher proposed the following hypotheses:

H1: There is a significant positive relationship between organizational commitment and internal whistleblowing intention.

H2: There is a significant positive relationship between organizational commitment and external whistleblowing intention.

\section{Model Specification:}

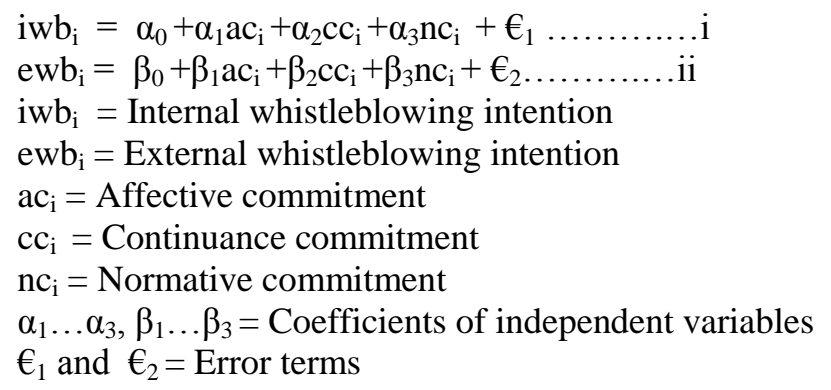

\section{Methods:}

The design used in this study was the survey research design. The purposive sampling technique was used in selecting 200 commercial bank workers in Benin City, Edo State, Nigeria. 200 copies of the questionnairewere distributed to workers in their places of work, and 191 useful questionnaires were retrieved which amounted to $96 \%$ response rate. Whistleblowing intentions were measured by a total of 8 items adopted from Ponnu, Naidu, \&Zamri (2008). These items consisted of 4 items each on internal and external whistleblowing intentions, and a 5-point likert scale was employed to rate statements and responses ranges from 1- 'very easy' to 5- 'very hard'.Sample items included: If you found wrongdoing in your workplace, how hard would you try to do the following? 
Internal Whistleblowing:I would report it to the appropriate persons within the organization.

External Whistleblowing:I would report it to appropriate authorities outside of the organization.

Organizational commitment was measured by 24 items adopted from Allen \& Meyer (1990). 8 items each measured affective commitment, continuance commitment and normative commitment and responses were on a 7-point likertscale which ranges from 1-strongly disagree to 7-strongly agree. Sample items include: I will be very happy to spend the rest of my career with this organization (affective commitment); It would be very hard for me to leave my organization right now, even if I wanted to (continuance commitment); One of the major reasons I continue to work for this organization is that I believe that loyalty is important and therefore feel a sense of moral obligation to remain (normative commitment). STATA (Version 13.0) Statistical software was used for data analysis.

\section{Results:}

Table 1 shows the respondents' demographic variables. The result reveals that $105(54.97 \%)$ and $86(45.02 \%)$ of the respondents are males and females respectively. Correspondingly, it was shown that 114(59.69\%) and 57(29.84\%) fall within the age brackets of 21-30years and 31-40years, 16(8.38\%) and 4(2.09\%) 41-50years and 51-60years respectively, while none of the respondents was within the age brackets of above 61years. On the highest educational qualification, it was found that majority of the respondents have obtained formal education or degrees like undergraduate and postgraduate certificates as captured by 114(59.69\%) and 56(29.32\%) respectively. The marital status of the respondents revealed that $84(42.98 \%)$ and 106(55.5\%) are single and married respectively, while only $1(0.52)$ was divorced.

Table 1: Respondents Bio-Data

\begin{tabular}{|c|c|c|c|c|}
\hline $\mathbf{S} / \mathbf{N}$ & Variables & Categories & $\begin{array}{c}\text { Frequency } \\
(n=191)\end{array}$ & $\begin{array}{c}\text { Percentage } \\
(\%)\end{array}$ \\
\hline \multirow[t]{3}{*}{1.} & Gender & Male & 105 & $54.97 \%$ \\
\hline & & Female & 86 & $45.03 \%$ \\
\hline & & Total & 191 & $100.0 \%$ \\
\hline \multirow[t]{6}{*}{2.} & Age & 21-30years & 114 & $59.69 \%$ \\
\hline & & 31-40years & 57 & $29.84 \%$ \\
\hline & & 41-50years & 16 & $8.38 \%$ \\
\hline & & 51-60years & 4 & $2.09 \%$ \\
\hline & & > 61years & - & - \\
\hline & & Total & 191 & $100.0 \%$ \\
\hline \multirow[t]{6}{*}{3.} & Highest Educational & Primary School & - & - \\
\hline & Qualification & Secondary School & - & - \\
\hline & & Diploma & 21 & $10.99 \%$ \\
\hline & & Degree & 114 & $59.69 \%$ \\
\hline & & Postgraduate & 56 & $29.32 \%$ \\
\hline & & Total & 191 & $100.0 \%$ \\
\hline \multirow[t]{4}{*}{4.} & MaritalStatus & Single & 84 & $43.98 \%$ \\
\hline & & Married & 106 & $55.50 \%$ \\
\hline & & Divorced & 1 & $0.52 \%$ \\
\hline & & Total & 191 & $100.0 \%$ \\
\hline
\end{tabular}

Source: Field Survey, 2019

In Table 2, the measures of average (mean), dispersion (standard deviation), and cronbach alpha (reliability) on whistleblowing intentions and organizational commitment dimensions were presented. The result shows that both internal whistleblowing intention (IWB) and external whistleblowing (EWB) had mean of 2.99 and 3.82 respectively, thus beating the cut-off mean of 2.50. On the other hand, organizational commitment dimensions (affective commitment, $\mathrm{AC}=4.50$; continuance commitment, $\mathrm{CC}=4.27$ and normative commitment, $\mathrm{NC}=4.27$ ) beat the mean cutoff benchmark of 3.50.The Cronbach alpha coefficient of all the study variables exceeded the 0.70 cut-off (Cronbach, 2004). The above result implies that the questionnaire items were good indicators for evaluating the connection between whistleblowing intentions and organizational commitment. 
Table 2: Measures of Average, Dispersion and Cronbach Alpha of the Study Variables

\begin{tabular}{|c|cccc|}
\hline Variables & Observations & Mean & Standard Deviation & Cronbach's Alpha \\
\hline IWB & 191 & 2.989948 & 1.00771 & 0.83 \\
\hline EWB & 191 & 3.824607 & 0.90139 & 0.78 \\
\hline AC & 191 & 4.497382 & 0.950240 .86 & \\
\hline NC & 191 & 4.270288 & 0.927560 .84 & \\
\hline
\end{tabular}

Source: Field Survey, 2019

Table 3 shows the results for Variance Inflation Factor (VIF). The mean VIF for the independent variables did not exceed the standardized VIF level $(1.06<10.0)$. This indicates the absence of multicollinearity among the independent variables.

Table 3: Variance Inflator Factor (VIF) Test

\begin{tabular}{r|cr}
\hline Variable & VIF & $1 /$ VIF \\
\hline nc & 1.09 & 0.919925 \\
ac & 1.06 & 0.940299 \\
CC & 1.04 & 0.960270 \\
\hline Mean VIF & 1.06 & \\
\hline
\end{tabular}

Source: Field Survey, 2019

Presented in Table 4 are the correlation coefficients between internal whistleblowing (IWB) and the dimensions of organizational commitment. The correlation matrix indicates a positive relationship between internal whistleblowing (IWB) and both continuance commitment (CC) and normative commitment (NC). However, a negative relationship was found between internal whistleblowing and affective commitment (AC). Also, none of the pairs of independent variables exceeded 0.8 , which also indicate that there is the nonexistence of multicollinearity among the pairs of independent variables.

Table 4: Correlation Matrix of Internal Whistleblowing \& Organizational Commitment

\begin{tabular}{r|rrrr}
\hline & iwb & ac & CC & nC \\
\hline$i w b$ & 1.0000 & & & \\
\hline ac & -0.1388 & 1.0000 & & \\
CC & 0.0031 & 0.1142 & 1.0000 & \\
nc & 0.0058 & 0.2335 & 0.1855 & 1.0000
\end{tabular}

Source: Field Survey, 2019

Presented in Table 5 are the correlation coefficients between external whistleblowing (EWB) and the dimensions of organizational commitment. The correlation matrix shows that the independent variables (AC, CC \& NC) are carrying positive signs and are thus positively correlated with EWB. Besides, none of the pairs of independent variables exceeded 0.8, which implies that there is the nonexistence of multicollinearity among the pairs of independent variables. 
Table 5: Correlation Matrix External Whistleblowing \& Organizational Commitment

\begin{tabular}{c|cccc}
\hline & ewb & ac & C & nc \\
\hline ewb & 1.0000 & & & \\
\hline a C & 0.1287 & 1.0000 & & \\
C C & 0.2238 & 0.1142 & 1.0000 & \\
nc & 0.1101 & 0.2335 & 0.1855 & 1.0000
\end{tabular}

Source: Field Survey, 2019

\section{Hypotheses testing:}

The multiple regression results showing organizational commitment (ac, cc, \&nc)as predictors of internal whistleblowing intention (iwb)are presented in Table 6. The R-squared value of 0.01 shows that organizational commitment predictors explain $1.00 \%$ of the systematic variation in internal whistleblowing intention. Also, it was revealed that a non-significant relationship existed between organizational commitment and internal whistleblowing intention $(f$-ratio $(3,187)=1.34$; Prob. $F=0.26>0.05)$. Hypothesis one (H1) was therefore rejected. Thus, there is a non-significant positive relationship between organizational commitment and internal whistleblowing intention. Also, the $\mathrm{t}$-test statistics showed that the variableaffective commitment (ac)(t-ratio $=-2.00$, Prob. $p=0.047<0.05)$ is significantly negatively related to internal whistleblowing intention, with $\beta$ coefficient of -0.16 . Continuance commitment(cc) and normative commitment (nc) showed a non-significant positive relationship ( $t$-ratio $=0.18$, Prob. $p=0.860>0.05$ ) and ( $t$-ratio $=0.51$, Prob. $p=0.613>0.05$ ) respectively. Besides, $\beta$ coefficients for $\mathrm{cc}$ and nc were 0.014 and 0.052 respectively, which were positive.

Table 6: Multiple Regression Results of Internal Whistleblowing Intention and OrganizationalCommitment

\begin{tabular}{|c|c|c|c|c|c|c|}
\hline Source & SS & $d f$ & MS & Number of obs & $=$ & 191 \\
\hline Model & 4.04755154 & 3 & 1.34918385 & Prob > F & $=$ & 0.2642 \\
\hline Residual & 188.893548 & 187 & 1.01012592 & R-squared & $=$ & 0.0210 \\
\hline Total & 192.941099 & 190 & 1.01547947 & $\begin{array}{l}\text { Adj R-squared } \\
\text { Root MSE }\end{array}$ & $=$ & $\begin{array}{l}0.0053 \\
1.0051\end{array}$ \\
\hline
\end{tabular}

\begin{tabular}{r|rrrrrr}
\hline iwb & Coef. & Std. Err. & $t$ & $\mathrm{P}>|t|$ & [95\% Conf. Interval] \\
\hline ac & -.1582575 & .0791308 & -2.00 & 0.047 & -.3143612 & -.0021538 \\
CC & .0141272 & .0802185 & 0.18 & 0.860 & -.1441223 & .1723766 \\
nc & .0524486 & .1035342 & 0.51 & 0.613 & -.1517965 & .2566938 \\
_cons & 2.787291 & .5554788 & 5.02 & 0.000 & 1.691481 & 3.883101 \\
\hline
\end{tabular}

\section{Source: Field Survey, 2019}

The multiple regression results showing organizational commitment (ac, cc, \&nc)as predictors of external whistleblowing intention (ewb) are presented in Table 7. The R-squared value of 0.05 shows that organizational commitment predictors explain $5.00 \%$ of the systematic variation in external whistleblowing intention. Also, it was revealed that a significant relationship existed between organizational commitment and external whistleblowing intention $(f$-ratio $(3,187)=4.21$; Prob. $F=0.01<0.05)$. $\mathbf{H} 2$ was therefore accepted. 
Thus, there is a significant positive relationship between organizational commitment and external whistleblowing intention. Also, the t-test statistics showed that the variablecontinuance commitment (cc) $(t$-ratio $=2.82$, Prob . $p=0.01<0.05$ )is significantly positively related to external whistleblowing intention, with $\beta$ coefficient of 0.20 . Affective commitment (ac) and normative commitment (nc) showed a non-significant positive relationship ( $t$-ratio $=1.28$, Prob. $p=0.20>0.05$ ) and ( $t$-ratio $=0.68$, Prob. $p=0.50>0.05)$ respectively. Besides, $\beta$ coefficients for ac and nc were 0.089 and 0.062 respectively, which were positive.

Table 7: Multiple Regression Results of External Whistleblowing Intention and Organizational Commitment

\begin{tabular}{|c|c|c|c|c|c|}
\hline Source & SS & $d f$ & MS & Number of obs $=$ & 191 \\
\hline Model & 9.75751443 & 3 & 3.25250481 & Prob $>F$ & $=0.0066$ \\
\hline Residual & 144.616831 & 187 & .773352038 & $\mathrm{R}$-squared $=$ & $=0.0632$ \\
\hline Total & 154.374346 & 190 & .812496556 & $\begin{array}{l}\text { Adj R-squared }= \\
\text { Root MSE }\end{array}$ & $\begin{array}{l}=0.0482 \\
=\quad .8794\end{array}$ \\
\hline
\end{tabular}

\begin{tabular}{r|rrrrrr}
\hline ewb & Coef. & Std. Err. & $t$ & P $>|t|$ & [95\% Conf. Interval] \\
\hline ac & .0888508 & .0692383 & 1.28 & 0.201 & -.0477377 & .2254393 \\
CC & .1980269 & .07019 & 2.82 & 0.005 & .0595609 & .3364929 \\
nc & .0618453 & .0905909 & 0.68 & 0.496 & -.1168663 & .2405568 \\
_cons & 2.315161 & .4860359 & 4.76 & 0.000 & 1.356343 & 3.273979 \\
\hline
\end{tabular}

Source: Field Survey, 2019

\section{Discussion of findings:}

The major finding of this study was that organizational commitment can significantly predict external whistleblowing intention, whereas it could not significantly predict internal whistleblowing intention. Although the coefficient of determination, R-Square was very small, it indicated that several other explanatory (independent) variables where excluded from our model. This was a limitation of the study. Future researchers should include more independent variables to the model to have a more robust explanation of whistleblowing intention in organizations in Nigeria.

Another finding of this study was that there exist a negative relationship between internal whistleblowing and affective commitment. This finding aligns with Saygan (2011) who contends that internal whistleblowing intention have a negative relationship with affective commitment. This finding makes sense as employees who exhibits affective commitment tends to be emotionally attached and loyal to the organization. Hence these employees find it difficult to blow the whistle when they discover wrongdoing, misconduct or unethical behavior in the organization. Employees also remain silent because of the repercussions resulting from whistleblowing behavior. According to Fapohunda, (2016), these repercussions include blacklisting, persecution, employee exclusions, poor performance ratings, fabricated accusation of personality and actions of the whistleblower.

Previous researchers have similarly found a positive relationship between whistleblowing and organizational commitment (Hayati\&Wulanditya, 2018; Miceli et al., 1991 and Manjughi\&Fasihizadeh, 2012). These findings however, contradict Sims \& Keenan (1998) and Mesmer-Magnus \&Viswesvaran (2005) who established that there was no relationship between whistleblowing and organizational commitment.

\section{Conclusion/Recommendations:}

In this present study, we examined the relationship between organizational commitment and whistleblowing intention among commercial bank employees in Nigeria. Briefly, the results suggest that there is a non-significant positive relationship between internal whistleblowing intention and organizational commitment. In addition, a significant positive relationship was found between external whistleblowing and organizational commitment. 
These findings are significant because the Nigerian Government is concern about corruption and places a high value on the whistleblowing policy that was launched in December 2016. Based on the findings of this study, the following recommendations are made:

- Human Resource Managers of commercial banks in Nigeria should organize training programmes/seminars for managers and employees to enable them develop a high level of organizational commitment, as this will help them report observed wrongdoing to appropriate authorities.

- The whistleblowing protection policy of the Nigerian Federal Government should be fully implemented in all our commercial banks. This will give commercial bank employees the moral courage to report wrongdoing within the organization.

- Autonomous reporting channels should be established in commercial banks and other institutions fighting corruption in Nigeria.

\section{References:}

Ahmad, S., George, S., \&Zubaidah, I. (2012). Internal whistleblowing intentions: A study of demographic and individual factors. Journal of Modern Accounting and Auditing, 8(11), 1632-1645.

Albdour, A.A., \&Altarawneh, I.I (2014). Employee Engagement and Organizational Commitment: Evidence from Jordan. International Journal of Business, 19(2), 192-212.

Allen, N.J., \& Meyer, J.P. (1990). The measurement and antecedents of affective, continuance, and normative commitment to the organization. Journal of Occupational Psychology, 63, 1-18.

Allen, N.J., \& Meyer, J.P. (1996). Affective, Continuance, and Normative commitment to the organization: An examination of construct validity. Journal of Vocational Behaviour, 49(3), 252-276.

Al-Jabari, B., \&Ghazzawi, I. (2019). Organizational commitment: A Review of the conceptual and empirical literature and a research agenda. International Leadership Journal, 11(1), 78-119.

Becker, T.E., \& Billings, R.S. (1993). Profiles of commitment: An empirical test. Journal of Organizational Behaviour, $14,177-190$.

Chen, L. (2019). A Review of research on whistleblowing. American Journal of Industrial and Business Management, 9, 295-305.

Cronbach, L.J. (2004). My current thoughts on coefficient alpha and successor procedures. Educational and Psychological Measurement, 64, 391-418.

Culiberg, B., \&Mihelic, K.K. (2017). The evolution of whistleblowing studies: A critical review and research agenda. Journal of Business Ethics, 146(4), 787-803.

Daily Trust (2019). Transparency International Ranking of Nigeria. Daily Trust Newspaper, Sunday November 17, Retrieved on November, 18, 2019 from https://www.dailytrust.com.ng/transparency-international-ranking-ofnigeria.html

Dyck, A., Morse, A., \&Zingalas, L. (2010). Who blows the whistle on corporate fraud? Journal of Finance, 65(6), 2213-2253.

Fapohunda, T.M. (2016). Gender: Precursor of whistleblowing intentions and reprisals. International Journal of Research in Humanities and Social Studies, 3(12), 19-27.

Hayati, N., \&Wulanditya, P. (2018). Attitudes towards whistleblowing, organizational commitment, ethical climate principles, and self-efficacy as determinants of fraud disclosures. The Indonesian Accounting Review, 8(1), 2535.

Jubb, P.B. (1999). Whistleblowing: A restrictive definition and interpretation. Journal of Business Ethics, 21, 77-94.

Klein, H.J., Molloy, J.C., \& Cooper, J.T.(2009). Conceptual foundations: Construct definitions and theoretical representations of workplace commitments. In Klein, H.J., Becker, T.E., Meyer, J.P. (Eds), Commitment in organizations: Accumulated wisdom and new directions (pp. 123-144). New York: Routledge/Taylor and Francis.

Manjughi, N., \&Fasihizadeh, N. (2012). Simple and multiple relationships between organizational commitment with whistleblowing in Nursing profession. Interdisciplinary Journal of Contemporary Research in Business, 4, 846-857.

Mercurio, Z.A. (2015). Affective commitment as a essence of organizational commitment: An integrative literature review. Human Resource Development Review, 14(4), 389-414.

Mesmer-Magnus, J.R., \&Viswesvaran, C. (2005). Whistleblowing in organizations: An examination of correlates of whistleblowing intentions, actions, and retaliation. Journal of Business Ethics, 62, 277-297. 
Meyer, J.P., \& Allen, N.J. (1997). Commitment in the workplace: Theory, research, and application. Sage Thousand Oaks, CA: Sage.

Miceli, M.P., Near, J.P., \&Schwenk, C.R. (1991). Who blows the whistle and why? Industrial \&Labour Relations Review, 45, 113-130.

Miceli, M.P., Dreyfus, S., \& Near, J.P. (2014). Outsider "whistleblower": conceptualizing and distinguishing "bellringing" behavior. In A.J. Brown., D. Lewis., R. Moberly(Eds.), International Handbook on Whistleblowing Research. Cheltenham: Edward Elgar.

Mowday, R.T., Steers, R.M., Porter, L.W.(1979). The measurement of organizational commitment. Journal of Vocational Behavior, 14(2), 224-247.

Nikolett, V., \&Nawangsari, L.C. (2019). Impact of Human Resource Management Practices: Factors influencing organizational citizenship behavior at KelapaGading Mall. International Journal of Scientific Research Publication, 9(2), 220-229.

Nishanthi, H.M., \&Kailasapathy, P. (2018). Employee commitment: The role of organizational socialization and protean career orientation. South Asian Journal of Human Resources Management, 5(1), 1-27.

Onuora, J.K., \&Uzoka, P.U. (2018). Whistleblowing and corruption in the public sector. Journal of Accounting and Financial Management, 4(6), 109-121.

O'Reilly III, C., \&Chatman, J.C. (1986). Organizational commitment and psychological attachment: The effects of compliance, identification, and internalization on prosocial behavior. Journal of Applied Psychology, 71, 492499.

Park, H., Rehg, M.T., \& Lee, D. (2005). The influence of Confucian Ethics and Whistleblowing Intentions: A study of South Korean Public Employees. Journal of Business Ethics, 58, 387-403.

Ponnu, C.H., Naidu, K., \&Zamri, W. (2008). Determinants of Whistleblowing. International Review of Business Research Papers,4(1),276-298.

Saygan, F.N. (2011). Relationship between affective commitment and organizational silence: A conceptual discussion. International Journal of Social Sciences and Humanity Studies, 3(2), 219-227.

Sims, R.L., \& Keenan, J.P. (1998). Predictors of external whistleblowing: Organizational and intrapersonal variables. Journal of Business Ethics, 17, 411-421.

Singh, A., \& Gupta, B. (2015). Job involvement, organizational commitment, professional commitment, and team commitment. Benchmarking: An International Journal, 22(6), 1192-1211.

Stinglhamber, F., Marique, G., Caesens, G., Desmette, D., Hansez, I., Hanin, D., \& Bertrand, F (2015). Emplyees' Organizational Identification and Affective Organizational commitment: An Integrative Approach. PLoS ONE, 10(4), e 0123955

Trevino, L.K.,\& Weaver, G.R. (2001). Organizational justice and ethics program "follow-through": Influences of employees' harmful and helpful behavior. Business Ethics Quarterly, 11(4), 651-671.

Wang, C.L., Indridason, T., \& Saunders, N.K ( 2010). Affective and Continuance commitment in public private partnership. Employee Relations, 32(4), 396-417 